MATEC Web of Conferences 10, 02005 (2014)

DOI: $10.1051 /$ matecconf/ 20141002005

(C) Owned by the authors, published by EDP Sciences, 2014

\title{
Building Investigation: Material or Structural Performance
}

\author{
M.Z. Yusof
}

School of Housing, Building and Planning, Universiti Sains Malaysia, 11800, Penang, Malaysia

\begin{abstract}
Structures such as roof trusses will not suddenly collapse without ample warning such as significant deflection, tilting etc. if the designer manages to avoid the cause of structural failure at the material level and the structural level. This paper outlines some principles and procedures of PDCA circle and QC tools which can show some clues of structural problems in terms of material or structural performance
\end{abstract}

\section{Introduction}

Assessment of building structures can be classified as assessment of material performance or assessment of structural performance. Assessment of material performance, normally involves the evaluation of mechanical and durability properties such as chloride penetration, corrosion of the materials etc. [1]. Furthermore, assessment of structural performance can be divided into two categories namely structural performance at serviceability limit state (SLS), and structural performance at Ultimate Limit State (ULS). Building structures can reach the serviceability limit state due to problems such as deflection, cracks, vibration, durability and fire resistance, and the ultimate limit state due to bending, shear, compression or direct tension as well as overturning [2].

\section{Application of PDCA in structures}

Deming's or PDCA circle could be introduced in building structural investigation. The PDCA circle uses a direct approach where at first the building structural investigator has to plan (P) the investigation work as instructed or as per agreed with the client. Furthermore, in order to achieve what has been planned, the building investigator has to do (D) or more correctly to say to carry out an inspection, investigation, performance test etc. by means of the direct method or indirect investigation method such Finite Element Analysis, (FEA) [3]. These include assessment of durability or structural performance using destructive test, non-destructive test, load testing, thermography, GPR method etc. In addition, the investigator has to ensure or check (C) or analyse the result of the investigation work on material performance, structural performance as to whether the result or analysis is reliable in order to give advice to the client concerning the nature of the steps that the client should take to overcome the problems identified in the building structure. If the result is insufficient, the building investigator has to take further action (A) such as carry out additional testing or change the method of testing before the client can take countermeasures or take the necessary action such as remedy, strengthening the elements, demolish, etc. [4].

Corresponding author: zaid_ysf@yahoo.com

This is an Open Access article distributed under the terms of the Creative Commons Attribution License 2.0, which permits unrestricted use, distribution, and reproduction in any medium, provided the original work is properly cited. 
Moreover, Figure 1 shows the work procedure of structural investigation based on the ISO 9001: 2000 (Design Consultancy Services) which was introduced by the author. The project was completely audited by the SIRIM QAS Sdn. Bhd. Detail explanations of these steps are illustrated as follows:

\section{(i) Input of received project}

After receiving a project from the client, the managing director, that is the engineer, has to obtain the necessary information from the client especially concerning the layout, construction drawing or design drawing such as substructures, internal plumbing, water reticulation, sewerage, mechanical and electrical (M \& E) if relevant [5].

\section{(ii) Appointment of project team}

The managing director has to explain the scope of work to the project team. Appointments of the team include project manager, engineer or designer and draughtsman of the project. Based on the size of the project, in some cases the engineer can act as a project manager as well as the designer.

\section{(iii) Site visit, decision and approval}

The appointed project manager or engineer needs to visit the site that requires the investigation work. The manager has to identify the nature of the problem at the site based on the scope of work given by the client. Furthermore, the project manager will determine the requirement of structural investigation in terms of drawing or equipment of the project such as PUNDIT, digital camera, hand microscope, surveying equipment etc.

\section{(iv) Investigation}

After this, the project manager, will investigate the condition of the structure, i.e. substructure and superstructure, and then decide on the types of testing or monitoring work required before remedying or rectifying the work on the structure. The monitoring works include load-displacement, crack detection, crack pattern as well as crack spacing. If the structural elements such as slabs and beams deflect, it is important to know at what degree the deflection is permitted in accordance with codes of practice that are used in the investigation [6].

\section{(v) Conduct a testing or monitoring}

The project manager has to perform testing or an investigation that requires additional information before remedying or rectifying work, controlling the work schedule on investigation work, approving payment to the firm or company which is involved in the investigation work such as land surveyor, contractor and also advise the client on the action that should be taken based on the testing or monitoring results [7].

\section{(vi) Analysis of results}

The results of the structural investigation will be analysed by the engineer using methods or certain codes of practice such as British Standard, European Standard, or other alternative adequacy methods before the engineer can advise the client regarding the necessary steps that should be taken by the client. They include remedy work at material level, strengthening, demolishing of the structure or replacement of a structural element. In addition, the engineer is also required to prepare a tender, bill of quantities, and details of structural drawings if the investigation demonstrates that the structure requires repair or remedy work [8]. 


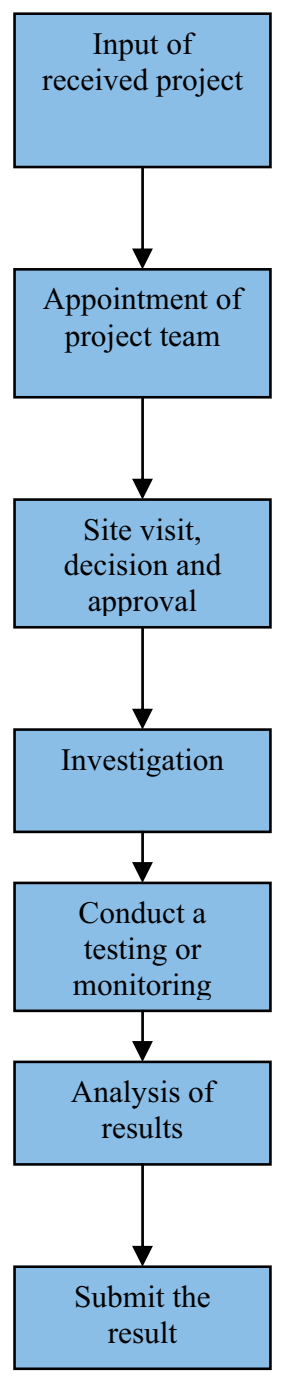

Figure 1. Flow of structural investigation

\section{Check sheet- material vs. structural}

As outlined earlier, the investigation work of building consists of two parts. The first part is investigation at material level and second part is investigation at structural level. The following QC tools, i.e. Check sheets (Table 1- Table 3) would be adequate to differentiate between the material level and the structural level investigation. 
Table 1. Examples of material level problem

\begin{tabular}{|c|l|l|}
\hline No & \multicolumn{1}{|c|}{ Problem } & \multicolumn{1}{|c|}{ Comments } \\
\hline 1 & Weight loss of concrete & $\begin{array}{l}\text { Weight loss due to the attack of seawater, acid, deterioration } \\
\text { of material etc. }\end{array}$ \\
\hline 2 & Corrosion of steel bars & $\begin{array}{l}\text { Ensure that corrosion on reinforcement will not reduce the } \\
\text { moment carrying capacity }\end{array}$ \\
\hline 3 & Dimensional instability & Shrinkage and expansion due to thermal effect \\
\hline 4 & $\begin{array}{l}\text { Effect of carbonation and sulphate } \\
\text { attack }\end{array}$ & Reduce concrete durability \\
\hline 5 & Insufficient concrete cover & $\begin{array}{l}\text { Thickness of concrete cover must follow the code of } \\
\text { practice }\end{array}$ \\
\hline
\end{tabular}

Table 2. Examples of structural level problem

\begin{tabular}{|c|l|l|}
\hline No & \multicolumn{1}{|c|}{ Problem } & \multicolumn{1}{c|}{ Comments } \\
\hline 1 & Active crack & Crack normally refer to superstructure \\
\hline 2 & Slanting building & $\begin{array}{l}\text { Tilt should less than allowable tilt in accordance to the } \\
\text { British Standard }\end{array}$ \\
\hline 3 & Effect of vibration on building & $\begin{array}{l}\text { Vibration effect will also reduce performance of building } \\
\text { structure }\end{array}$ \\
\hline 4 & Substructure problem & $\begin{array}{l}\text { Number, length, size, types, total number of piles etc. which } \\
\text { do not follow design specification }\end{array}$ \\
\hline 5 & $\begin{array}{l}\text { Excessive } \\
\text { deflection }\end{array}$ & $\begin{array}{l}\text { Beam with too long span will cause excessive deflection } \\
\text { and may not comply with code of practice }\end{array}$ \\
\hline 6 & Fatigue & $\begin{array}{l}\text { Should be considered for structure designed under cyclic } \\
\text { loading }\end{array}$ \\
\hline
\end{tabular}

Table 3. Example of design problems

\begin{tabular}{|c|l|l|}
\hline No & \multicolumn{1}{|c|}{ Problem } & \multicolumn{1}{|c|}{ Comments } \\
\hline 1 & $\begin{array}{l}\text { Building or function of structural } \\
\text { element changed }\end{array}$ & $\begin{array}{l}\text { For example lightweight industrial building at first, } \\
\text { subsequently change to other purpose such as semi- } \\
\text { heavyweight industrial building. }\end{array}$ \\
\hline 2 & $\begin{array}{l}\text { Area of tension or compression } \\
\text { reinforcement }\end{array}$ & $\begin{array}{l}\text { This design defect will affect building or structural load } \\
\text { carrying capacity }\end{array}$ \\
\hline 3 & Software constraint used in design & $\begin{array}{l}\text { Depends on type model used. In addition, constraint on } \\
\text { computer software programme such as boundary condition, } \\
\text { initial imperfection as well as cyclic loading }\end{array}$ \\
\hline 5 & $\begin{array}{l}\text { Extra loads on the existing structure } \\
\text { consideration }\end{array}$ & $\begin{array}{l}\text { Extra loading such as mobile crane, which is not } \\
\text { considered during the design process will also affect } \\
\text { structure integrity. }\end{array}$ \\
\hline 6 & $\begin{array}{l}\text { Connections } \\
\text { High-rise building needs to consider wind load into }\end{array}$ \\
\hline 7 & $\begin{array}{l}\text { Structure designed limit to static } \\
\text { loading only }\end{array}$ & $\begin{array}{l}\text { Method of connection, lap lengths, shape, size of } \\
\text { curtailment etc. do not follow the code of practice }\end{array}$ \\
\hline 8 & $\begin{array}{l}\text { Computer miscalculations resulted of } \\
\text { wrong input data }\end{array}$ & $\begin{array}{l}\text { For certain cases, the effect of cyclic loading, vibration, } \\
\text { impact load should be considered } \\
\text { especially for structural drawing }\end{array}$ \\
\hline
\end{tabular}




\section{Conclusions}

The QC tools, i.e. check sheets, highlighted in this paper would be able to show some clue 5W1H (when, what, who, when, where and how) of structural damage, failure at material level or structural level. The skill or ability of an engineer, technologist, pathologist to identify types or the nature of the problem or problems with respect to material performance or structural performance is important in building investigation. However, it should be noted that not all problems related to the structure can be referred to the code of practice since some problems require experience in design, site or even experience in computational modelling using finite element simulation software such as LUSAS, ABAQUS, ANSYS etc. to simulate the material and structural performance during loading and unloading.

\section{References}

1. Application Manual LUSAS Civil and Structural Version 14.7, United Kingdom, 2011

2. The British Standard Institution. Structural Use of Concrete(BS8110), United Kingdom, 1997

3. N. Iwasaki, Konkurito no Tokusei (in Japanese), Kyoritsu shuppan kabushikikaisha, Japan, 1975

4. Paul A. Nee, ISO 9000 in Construction, John Wiley and Sons, (1993)8-23

5. Design of reinforced concrete flat slabs to BS 8110, Construction Industry Research and Information Association (CIRIA), 1994, pp: 2-3

6. Claes Dyrbye, Svend Ole Hansen, Wind Load on Structures, John Wiley and Sons, 1997, pp: 1-3

7. J.M. Dulieu-Barton et. all, Damage Assessment of Structures, Trans Tech Publication Ltd., 2003, pp: 307-314

8. M.Z. Yusof, Quality Control and Equipment in Industrial Technology (in Malay), Dewan Bahasa dan Pustaka, 1 (1996) 1-12 